\title{
SYSTEMATIC REVIEW OF RECOVERY OF SPINAL CORD INJURY WITH ANTIOXIDANT THERAPY
}

\author{
REVISÃO SISTEMÁTICA DA RECUPERAÇÃO DE TRAUMA RAQUIMEDULAR COM TERAPIA \\ ANTIOXIDANTE
}

\section{REVISIÓN SISTEMÁTICA DE RECUPERACIÓN DE TRAUMA RAQUIMEDULAR CON TERAPIA ANTIOXIDANTE}

Marco Antonio Eduardo Koff¹, Lukman Olalekan Ajiboye², Natália Diel Lisboa'1, Asdrubal Falavigna ${ }^{1}$

1. Laboratory of Basic Studies on Spinal Cord Pathologies, Department of Neurosurgery, University of Caxias do Sul, Caxias do Sul, Rio Grande do Sul, Brazil.

2. Department of Orthopaedic and Trauma, Usmanu Danfodiyio University Teaching Hospital, Sokoto, Nigeria.

\begin{abstract}
The objective of the paper is to analyze the frequency and efficacy of experimental studies with antioxidant therapy. A search was conducted in the pubmed.gov database using the keywords "antioxidants" AND "spinal cord injury", from January 2000 to December 2015, resulting in 686 articles. Studies of non-traumatic injuries, non-antioxidant therapies, absence of neurological and functional evaluation, and non-experimental studies were excluded, leaving a total of 43 articles. The most used therapies were melatonin (16.2\%), quercetin (9.3\%), epigallocatechin and edaravone (6.9\%). The most frequent route of administration was intraperitoneal (72.09\%). The dose and mode of administration varied greatly, with a single dose being the most commonly used (39.53\%). The time elapsed from trauma to treatment was 0-15 minutes (41.8\%), 15-60 minutes (30\%) and over 60 minutes (10.6\%). Histological analysis was performed in 32 studies (74.41\%). The BBB scale was the main functional measure applied (55.8\%), followed by the inclined plane test (16.2\%) and the Tarlov scale (13.9\%). Positive outcomes were observed in 37 studies (86.04\%). The heterogeneity of antioxidant therapy, with different types, doses, and measurements observed, limits the comparison of efficacy. Standardized protocols are required to make clinical translation possible.
\end{abstract}

Keywords: Antioxidants; Spinal cord injuries; Neurology; Neurosurgery; Review.

\section{RESUMO}

O objetivo do presente estudo é analisar a frequência e a eficácia dos estudos experimentais com terapia antioxidante. Realizou-se uma pesquisa na base de dados pubmed.gov usando as palavras-chave "antioxidants" (antioxidantes) AND "spinal cord injury" (trauma raquimedular), de janeiro de 2000 a dezembro de 2015, resultando em 686 artigos. Estudos de lesões não traumáticas, terapias não antioxidantes, ausência de avaliação neurológica e funcional e estudos não experimentais foram excluídos, restando 43 artigos. As terapias mais utilizadas foram melatonina (16,2\%), quercetina (9,3\%), epigalocatequina e edaravona (6,9\%). A via de administração mais frequente foi intraperitoneal (72,09\%). A posologia e o modo de administração tiveram grande variação, sendo que a dose única foi a forma mais frequente (39,53\%). O tempo decorrido desde o trauma até a instituição do tratamento foi de 0 a 15 minutos (41,8\%), 15 a 60 minutos (30\%) e acima de 60 minutos (10,6\%). A análise histológica foi realizada em 32 estudos (74,41\%). O sistema de escala BBB foi a principal medida funcional aplicada (55,8\%), seguida de teste com plano inclinado (16,2\%) e a escala de Tarlov (13,9\%). Os desfechos positivos foram observados em 37 estudos (86,04\%). A heterogeneidade da terapia antioxidante com diferentes tipos, doses e medições observadas limita a comparação da eficácia. Protocolos padronizados são necessários para tornar possível a tradução clínica.

Descritores: Antioxidantes; Traumatismos da medula espinal; Neurologia; Neurocirurgia; Revisão.

\section{RESUMEN}

El objetivo del presente estudio es analizar la frecuencia y eficacia de los estudios experimentales con terapia antioxidante. Se realizó una búsqueda en la base de datos pubmed.gov utilizando las palabras clave "antioxidants" (antioxidantes) AND "spinal cord injury" (trauma raquimedular), de enero de 2000 a diciembre de 2015, y se encontraron 686 artículos. Se excluyeron los estudios de lesiones no traumáticas, terapias no antioxidantes, con ausencia de evaluación neurológica y funcional y los estudios no experimentales, quedando 43 artículos. Las terapias más utilizadas fueron melatonina (16,2\%), quercetina (9,3\%), epigalocatequina y edaravona (6,9\%). La vía de administración más común fue intraperitoneal (72,09\%). La dosificación y administración fueron variadas, pero la dosis única fue la forma más frecuente (39,53\%). El tiempo trascurrido desde el trauma a la iniciación del tratamiento fue de 0-15 minutos (41,8\%), 15 a 60 minutos (30\%) y más de 60 minutos (10,6\%). El análisis histológico se realizó en 32 estudios (74,41\%). El sistema de la escala BBB se aplicó como la principal medición funcional (55,8\%), seguida por la prueba del plano inclinado (16,2\%) y la escala de Tarlov (13,9\%). Se observaron resultados positivos en 37 estudios (86,04\%). La heterogeneidad de la terapia antioxidante con diferentes tipos, dosis y mediciones observados limita la comparación de la eficacia. Son necesarios protocolos estandarizados para tornar posible la traducción clínica.

Descriptores: Antioxidantes; Traumatismos de la médula espinal; Neurología; Neurocirugía; Revisión. 


\section{INTRODUCTION}

Spinal cord injury (SCI) can occur by traumatic or ischemic event. Following the primary injury, cellular necrosis and tissue degeneration are the secondary events, caused mainly by hypoxia and ischemia., ${ }^{1,2}$ A reduction in blood flow and microvascular abnormalities were demonstrated, leading to an increase in intracellular free radical species. ${ }^{3,4}$ Lipid peroxidation of the cell membrane has a novel role in the pathophysiology of neuronal lesion. ${ }^{2}$

There is no effective treatment to prevent the secondary damage caused by SCl. ${ }^{5}$ Corticosteroids were used to reduce edema formation and inflammatory events, with controversial results. ${ }^{3,6-9}$ Investigations to find a specific therapy to control the formation of free radicals are ongoing. ${ }^{10}$ The role of antioxidant drugs and hyperbaric oxygenic therapy is also being discussed. ${ }^{11,12}$

There are many publications that focus on antioxidant treatment after $\mathrm{SCl}$, with different neurological outcomes. The present study analyzes the various types of antioxidant drugs used in experimental $\mathrm{SCl}$, in order to define the most common and effective ones.

\section{MATERIALS AND METHODS}

A literature review was carried out in the database pubmed. gov, on December 13, 2015, using the keywords "antioxidants" AND "spinal cord injury", without filters. The selection of keywords was based on MeSH terms structure. The papers included were in vivo SCl studies treated by antioxidant therapy from January 2000 to December 2015. A total of 686 articles were found, which were then reviewed by two independent observers, considering the exclusion criteria reported in Figure 1. Full text PDFs of potentially relevant articles were obtained, in order to better select the articles.

The inclusion criteria were: experimental study in rats with $\mathrm{SCl}$ treated with antioxidant drugs and followed up to verify functional recovery. Articles in English, Spanish or Portuguese were included. The exclusion criteria were: lack of abstract, therapies other than antioxidant therapy, studies in animals other than rats, review articles, epidemiological or case-report studies, and lack of neurological and histological assessment.

The variables analyzed in the selected papers were: (I) year of publication, (II) type of the antioxidant drug used, (III) mechanism of action, (IV) posology, (V) administration form, (VI) elapsed time between the trauma and the treatment, and (VII) assessment of motor recovery and histology. ${ }^{13-55}$ (Table 1)

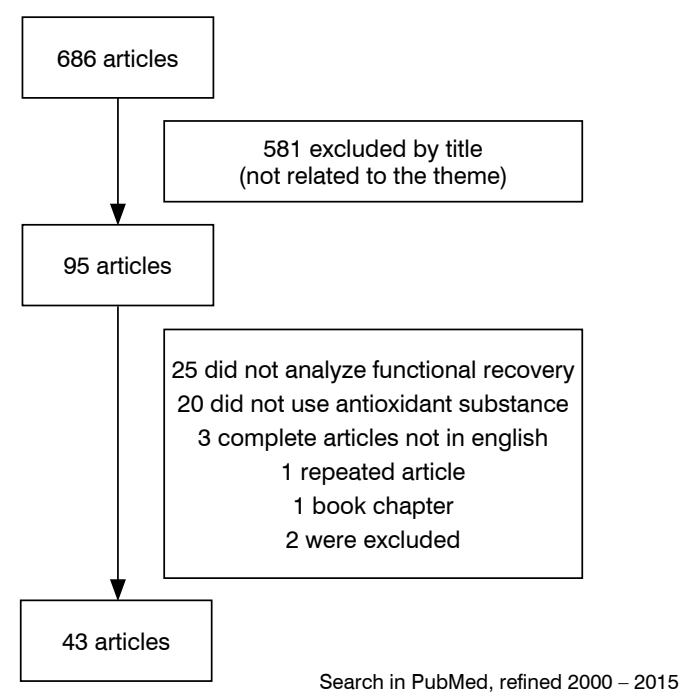

Figure 1. Flowchart. The search resulted in 686 articles. After applying the exclusion and inclusion criteria, 43 papers remained.
The year of publication was shown as a frequency graph, and the annual publication rate was determined by Pearson's Correlation and Simple Linear Regression, obtaining the slope ("b" coefficient). For both, statistics, the software program SPSS Statistics v. 24 for Mac (IBM, New York, USA) was used. Significance was defined as $p<0.05$.

"The study was a review and systematic analysis of scientific articles published on PubMed. In this case, there was no need for prior authorization by an ethics committee, as the works selected for the study were expressly authorized by their respective ethics committees. This study reviewed and analyzed these publications, and there was no contact with or prospective or retrospective data on animals or patients in any phase."

\section{RESULTS}

\section{Paper selection and inclusion}

Initially, 686 articles were retrieved. After analyzing each paper and applying the inclusion and exclusion criteria, forty-three articles were included in the study. (Figure 1)

The studies were reported according to the year of publication on PubMed: 2000-2004 (5 articles, 11.6\%), 2005-2009 (13 articles, $30.2 \%$ ), and $2010-2015$ (25 articles, 58.1\%). A mean of 3.6 papers were published per year. There was a significant increase in the number of publications in past 15 years (slope $=0.33, r=0.69$, $p=0.012$ ). (Figures 2 and 3 )

\section{Antioxidant therapy}

The most common drug used was melatonin ( 7 articles, $16.2 \%)$, followed by quercetin (4 articles, $9.3 \%$ ), epigallocatechin (3 articles, 6.9\%), and edaravone (3 articles, 6.9\%). The most frequent administration route was intraperitoneal in 31 papers and oral or nasogastric tube in 8 papers. (Table 1) ${ }^{13}$ - The posology and frequency showed wide variation that did not depend on the type of drug administered. Most of the articles used one dose only (17 articles, 39.5\%), more than 7 doses (9 articles, $20.9 \%$ ) and two doses (6 articles, 13.9\%).

The elapsed times from SCl to treatment was 0-15 minutes (18 articles, $41.8 \%$ ), 15 to 60 minutes (13 articles, 30\%), and after 1 hour (5 articles, 10.6\%). (Table 2) One study was classified separately because the treatment was started 5 minutes before SCI. Six papers (13.9\%) did not specify the time of drug administration after SCI. Eighteen studies started treatment immediately after SCl.

\section{Functional recovery}

Basso, Bresnahan and Beattie (BBB scale system) was used to perform the functional measurement in 24 articles (55.8\%). The following tests were inclined plane test (16.2\%) and Modified Tarlov Scale (13.9\%)

Histology was performed to analyze the efficacy in 32 articles (74.41\%).

\section{Time of observation}

The follow-up time of the animal was less than one week (14 articles, 32.5\%), 2 weeks (6 articles, 13.9\%), 3 weeks (8 articles, $18.6 \%), 4$ weeks (8 articles, 18.6\%) and more than 4 weeks (5 articles $11.6 \%$ ) (Table 1). Two articles do not report the follow-up time. (Table 2)

\section{Outcomes}

Positive outcomes were observed in 37 papers (86\%) after antioxidant treatment.

Negative outcomes were observed in 6 studies (13.9\%). Two papers with negative outcomes started treatment immediately after trauma, using melatonin and agmatine as antioxidant therapy. 
Table 1. Papers included in the study.

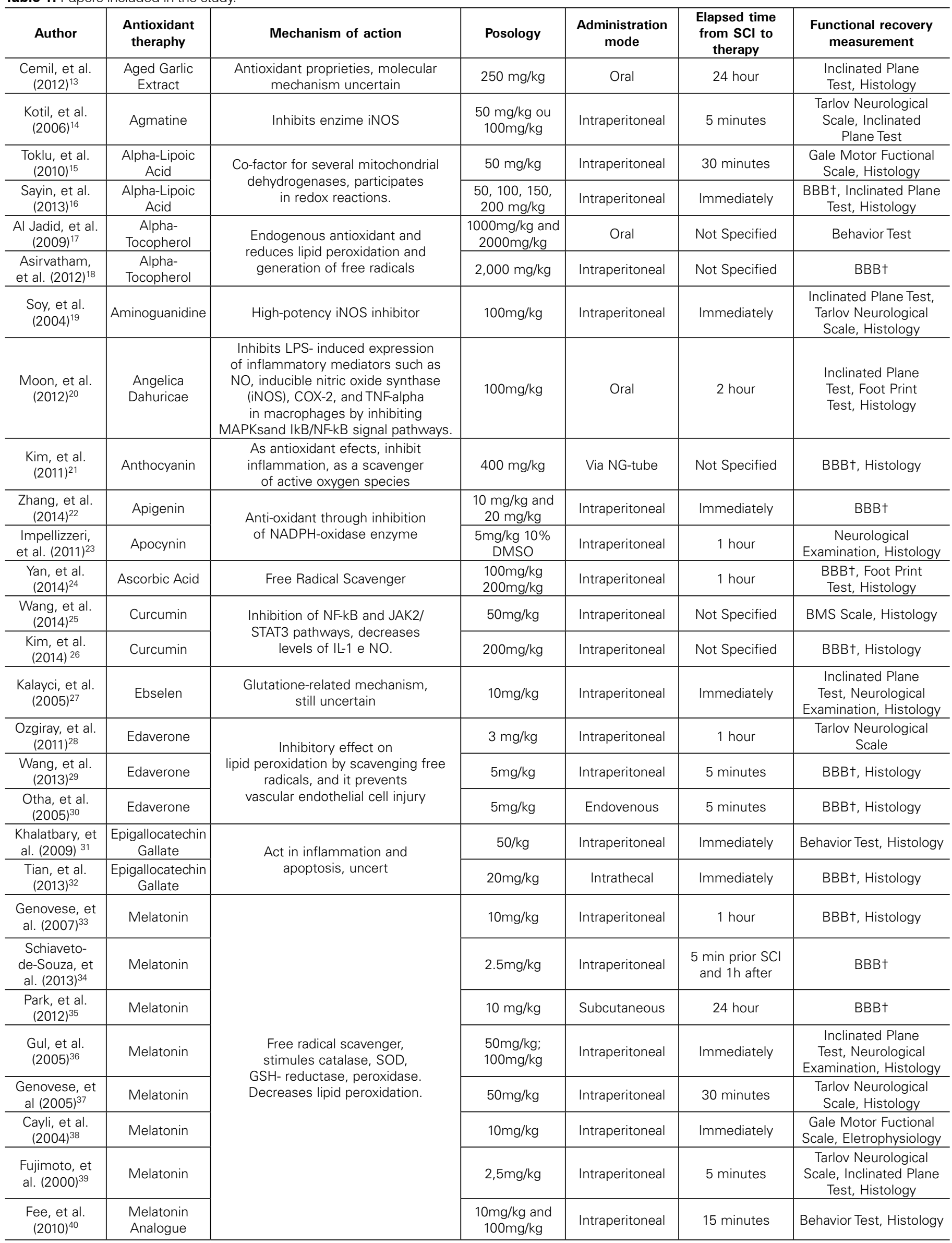


Table 1. Papers included in the study.

\begin{tabular}{|c|c|c|c|c|c|c|}
\hline Author & $\begin{array}{l}\text { Antioxidant } \\
\text { theraphy }\end{array}$ & Mechanism of action & Posology & $\begin{array}{l}\text { Administration } \\
\text { mode }\end{array}$ & $\begin{array}{l}\text { Elapsed time } \\
\text { from SCI to } \\
\text { therapy }\end{array}$ & $\begin{array}{c}\text { Functional recovery } \\
\text { measurement }\end{array}$ \\
\hline $\begin{array}{l}\text { Liu, et. Al. } \\
(2013)^{41}\end{array}$ & Mn (III) Tetrakis & $\begin{array}{c}\text { Potentializes SOD activity } \\
\text { and scavengers ROS }\end{array}$ & $4 \mathrm{mg} / \mathrm{kg}$ & Intrathecal & Immediately & BBBt, Histology \\
\hline $\begin{array}{l}\text { Hillard, et al. } \\
\qquad(2004)^{42}\end{array}$ & Tempol & $\begin{array}{l}\text { Stimulate SOD catalytic activity, also } \\
\text { inhibits hydroxyl radical generation by } \\
\text { oxidizing transition metals necessary } \\
\text { for Haber-Weiss/Fenton reactions. }\end{array}$ & $\begin{array}{l}69 \mathrm{mg} / \mathrm{kg} \\
138 \mathrm{mg} / \mathrm{kg} \\
275 \mathrm{mg} / \mathrm{kg} \\
550 \mathrm{mg} / \mathrm{kg}\end{array}$ & Intraperitoneal & 20 minutes & BBB†, Histology \\
\hline $\begin{array}{l}\text { Ling, et al. } \\
(2013)^{43}\end{array}$ & Mn (III) Tetrakis & $\begin{array}{l}\text { Potentializes SOD activity } \\
\text { and scavengers ROS }\end{array}$ & $10 \mathrm{mg} / \mathrm{kg}$ & Intraperitoneal & 1 hour & Histology \\
\hline $\begin{array}{l}\text { Cavus, et } \\
\text { al. }(2014)^{44}\end{array}$ & Montelukast & $\begin{array}{l}\text { Leukotrien receptor antago- nist } \\
\text { that specifically inhibites sodium } \\
\text { cisteinyl leukotrien CysLT1 receptor, } \\
\text { diminishing inflammatory process }\end{array}$ & $5 \mathrm{mg} / \mathrm{kg}$ & Intraperitoneal & Immediately & $\begin{array}{l}\text { Tarlov Neurological } \\
\text { Scale, Histology }\end{array}$ \\
\hline $\begin{array}{l}\text { Kanter, et } \\
\text { al. }(2006)^{45}\end{array}$ & Nigella Sativa & Anti-inflammatory, immunomodulatory & $0,2 \mathrm{ml} / \mathrm{kg}$ & Intraperitoneal & Immediately & $\begin{array}{c}\text { Inclinated Plane } \\
\text { Test, Neurological } \\
\text { Examination, Histology }\end{array}$ \\
\hline $\begin{array}{l}\text { Assis, et al. } \\
(2014)^{46}\end{array}$ & Proantrocyanidin & $\begin{array}{c}\text { Stimulates SOD, inhibits NDMA } \\
\text { glutamate receptors }\end{array}$ & $10 / \mathrm{mg} / \mathrm{kg}$ & Intraperitoneal & 1 hour & BBB†, Grip Force Test \\
\hline $\begin{array}{l}\text { Schultke, et } \\
\text { al. }(2010)^{47}\end{array}$ & Quercitin & \multirow{4}{*}{ Scavenger, decreases lipid peroxidation } & $25 \mathrm{mmol} / \mathrm{kg}$ & Intraperitoneal & 1 hour & BBBt, Histology \\
\hline $\begin{array}{c}\text { Song, et al. } \\
(2013)^{48}\end{array}$ & Quercitin & & $0,2 \mathrm{mg} / \mathrm{kg}$ & Intraperitoneal & 1 hour & BBBt, Histology \\
\hline $\begin{array}{l}\text { Schultke, et } \\
\text { al. }(2003)^{49}\end{array}$ & Quercitin & & $\begin{array}{c}5,25,50 \\
100 \mathrm{mmol} / \mathrm{kg} \\
\end{array}$ & Intraperitoneal & 1 hour & BBBt, Histology \\
\hline $\begin{array}{l}\text { Genovese, et } \\
\text { al. }(2006)^{50}\end{array}$ & Quercitin & & $30 \mathrm{mg} / \mathrm{kg}$ & Oral & 1 hour & BBBt, Histology \\
\hline $\begin{array}{l}\text { Ates, et al. } \\
(2006)^{51}\end{array}$ & Resveratrol & \multirow{2}{*}{$\begin{array}{l}\text { Anti-oxidation effect, suppression } \\
\text { of immunoreactivity, reduction of } \\
\text { inflammatory cytokines including IL- } \\
1 \beta, \text { IL-10, TNF-a, and myeloperoxidase, } \\
\text { inhibition of injury-induced apoptosis }\end{array}$} & $100 \mathrm{mg} / \mathrm{kg}$ & Intraperitoneal & $24 h$ & $\begin{array}{c}\text { Motor Function Score, } \\
\text { Inclinated Plane } \\
\text { Test, Histology }\end{array}$ \\
\hline $\begin{array}{l}\text { Liu, et. Al. } \\
(2011)^{52}\end{array}$ & Resveratrol & & $200 \mathrm{mg} / \mathrm{kg}$ & Intraperitoneal & Not Specified & $\begin{array}{c}\text { BBBt, Behavior } \\
\text { Test,Locomotor Rating } \\
\text { Scale, Histology }\end{array}$ \\
\hline $\begin{array}{l}\text { Yune, et al. } \\
(2009)^{53}\end{array}$ & $\begin{array}{l}\text { Scutellaria } \\
\text { Baicalensis }\end{array}$ & $\begin{array}{l}\text { Inhibition lipopolysaccharide- } \\
\text { induced expression and anti- } \\
\text { inflammatory proprieties }\end{array}$ & $\begin{array}{l}30,100, \text { or } \\
300 \mathrm{mg} / \mathrm{kg}\end{array}$ & Oral & 2 hour & $\begin{array}{l}\text { BBBt, Footprint } \\
\text { Test, Histology }\end{array}$ \\
\hline $\begin{array}{l}\text { Sharma, et } \\
\text { al. }(2006)^{54}\end{array}$ & $\begin{array}{c}\text { Sintetic }(\mathrm{H}- \\
\text { 29051) }\end{array}$ & Melatonin Analogue & $50 \mathrm{mg} / \mathrm{kg}$ & Via NG-tube & 10 minutes & $\begin{array}{l}\text { Inclinated Plane } \\
\text { Test, Histology }\end{array}$ \\
\hline $\begin{array}{l}\text { Serarslan, et } \\
\text { al. }(2010)^{55}\end{array}$ & Tadalafil & $\begin{array}{c}\text { Aa selective inhibitor } \\
\text { of cyclic guanosine } \\
\text { monophosphate (cGMP)-specific } \\
\text { phosphodiesterase type } 5\end{array}$ & $2 \mathrm{mg} / \mathrm{kg}$ & Via NG-tube & Immediately & $\begin{array}{l}\text { Neurological } \\
\text { Examination }\end{array}$ \\
\hline
\end{tabular}

Papers included and variables analyzed. † BBB (Basso, Bresnahan and Beattie scale system).

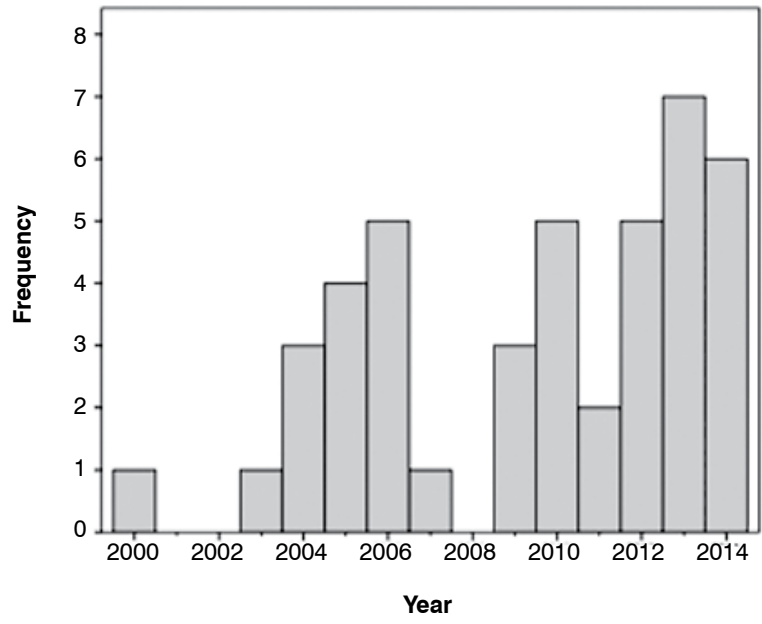

Figure 2. Frequency. The articles were divided by year of publication.

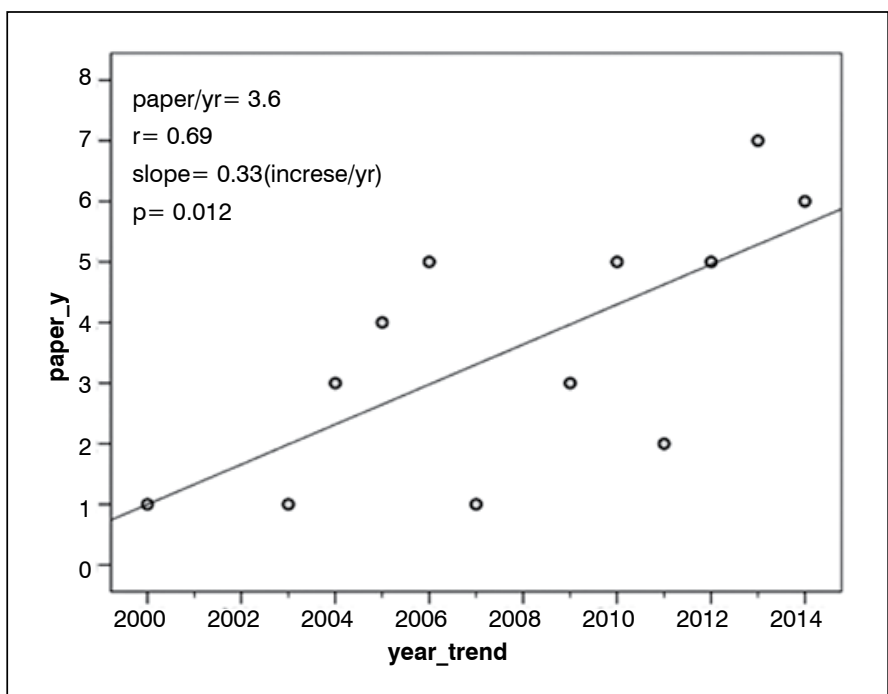

Figure 3. Statistical analysis. Pearson's Correlation and Linear Regression were used to obtain the slope. 
Table 2. Variables observed in the study.

\begin{tabular}{|c|c|c|}
\hline Variable & Number of articles & $\%$ \\
\hline \multicolumn{3}{|l|}{ Antioxidant } \\
\hline Melatonin & 7 & 16.2 \\
\hline Quercitin & 4 & 9.3 \\
\hline Epigalloccatecin & 3 & 6.9 \\
\hline Edaverone & 3 & 6.9 \\
\hline Resveratrol & 2 & 4.6 \\
\hline Curcumin & 2 & 4.6 \\
\hline Alpha-Licoic Acid & 2 & 4.6 \\
\hline Other* & 20 & 46.5 \\
\hline \multicolumn{3}{|l|}{ Administration mode } \\
\hline Intraperitoneal & 31 & 72 \\
\hline Oral/Nasogastric Tube & 8 & 18.6 \\
\hline Intrathecal & 2 & 4.6 \\
\hline Subcutaneous & 1 & 2.3 \\
\hline Intravenous & 1 & 2.3 \\
\hline \multicolumn{3}{|l|}{ Total dosage } \\
\hline 1 Dose & 17 & 39.5 \\
\hline 2 Doses & 6 & 13.9 \\
\hline 3 Doses & 3 & 6.9 \\
\hline 4 Doses & 2 & 4.6 \\
\hline 5 Doses & 1 & 2.3 \\
\hline 7 Doses & 4 & 9.3 \\
\hline$>7$ doses & 9 & 20.9 \\
\hline \multicolumn{3}{|l|}{ Functional recovery } \\
\hline $\mathrm{BBB}+$ & 24 & 55.8 \\
\hline Inclinated Plain Test & 7 & 16.2 \\
\hline Modified Tarlov Scale & 6 & 13.9 \\
\hline Other & 6 & 13.9 \\
\hline \multicolumn{3}{|c|}{ Elapsed time trauma to therapy } \\
\hline 0-15 minutes & 18 & 41.8 \\
\hline $15 \mathrm{~min}-30 \mathrm{~min}$ & 3 & 6.9 \\
\hline $30 \mathrm{~min}-60 \mathrm{~min}$ & 10 & 23.2 \\
\hline$>60 \min$ & 5 & 11.6 \\
\hline Not Specified & 6 & 13.9 \\
\hline \multicolumn{3}{|l|}{ Time of observation } \\
\hline$<1$ week & 14 & 32.5 \\
\hline 1 week - 2 weeks & 6 & 13.9 \\
\hline 2 weeks - 3 weeks & 8 & 18.6 \\
\hline 3 weeks - 4 weeks & 2 & 4.6 \\
\hline 4 weeks & 6 & 13.9 \\
\hline$>4$ weeks & 5 & 11.6 \\
\hline Not specified & 2 & 4.6 \\
\hline
\end{tabular}

The variables studied and its frequencies are resumed in this table. *Other type of antioxidant are presented in Table 1. † BBB (Basso, Bresnahan and Beattie scale system).

\section{DISCUSSION}

After $\mathrm{SCl}$, the inflammatory response occurs by cellular activation in order to reorganize the damaged tissue. This process increases the intensity and the volume of the lesion. Antioxidant therapy seeks to minimize the cellular effects of hypoxia and ischemia, leading to a better functional outcome after trauma. ${ }^{1-4}$ The present study showed better outcomes in 37 studies (86\%) where antioxidant therapy was used after experimental SCl. The most common therapy was the use of melatonin by the intraperitoneal route immediately after trauma.

Antioxidants are subdivided into two categories based on their hydrophilic or hydrophobic characteristics. Hydrophilic substances interact with intracellular enzymes, reducing reactive species production in the mitochondrial system by chemical reduction. Hydrophobic substances protect the cell membranes from damage.

Hypoxia secondary to SCI leads to free radical formation and lipid peroxidation, whereby lipids from plasmatic and intracellular membranes are converted by reactive species into malondialdehyde, leading to destruction of the membrane structure. This disarrangement of the intracellular membranes leads to activation of apoptosis, culminating in neuronal damage, with loss of motor, sensitive and autonomic functions, or even death. ${ }^{56,57}$ Antioxidant therapy blocks this cascade by scavenging free radicals and inhibiting different enzymes, such as superoxide-dismutase, glutathione peroxidase and catalase. ${ }^{12}$

\section{Number of doses and start of treatment}

Eight papers had an incomplete or partial description of the methods used; they did not specify the number of doses given $(n=6)$ or time treatment was started $(n=2)$. This information is essential to analyze its efficacy and verify which drug is the best for a clinical trial.

It was difficult to analyze the efficacy of antioxidant therapy because of the different method and types of drugs used. Starting therapy before trauma was not clinically relevant. Five articles started the treatment 1 hour after trauma, making clinical translation possible.

\section{Analysis of functional recovery}

The majority of the articles (28 papers, $82.3 \%$ ) completed the analysis of functional recovery at 3 weeks. It is known that the inflammatory process is reduced slowly and gradually. There is evidence to support the hypothesis that 4 weeks is the minimum time needed to analyze the histological and functional recovery. ${ }^{58}$ An analysis period of less than 4 weeks is insufficient to correctly determine the response to the treatment.

The limitations of the study were missing information, the different types of antioxidant therapy, the different doses, and different times elapse between the trauma and the start of therapy. The present article is the most complete and up-to-date review of antioxidant therapy in $\mathrm{SCl}$.

As future perspectives, the research group will design an in vivo experimental study to analyze the efficacy of antioxidant therapy after $\mathrm{SCl}$, to provide evidence for clinical translation.

\section{FINAL REMARKS}

The literature shows heterogeneity of antioxidant treatment with different types, doses, measurements that limit the comparison of efficacy. Standardized protocols for antioxidant therapy need to be designed to make the clinical translation viable.

\section{ACKNOWLEDGMENTS}

\section{AOSpine Latin America}

All the authors declare that there are no conflicts of interest regarding this article. 
CONTRIBUTIONS OF THE AUTHORS: This manuscript, which is a multi-institutional study, has four authors. Each author contributed individually and significantly to the development of the manuscript. MAEK and AF were the main contributors to the writing of the manuscript. MAEK, LOA and NA carried out the bibliographic research, reviewed the manuscript and contributed to the intellectual concept of the study. AF performed the final evaluation of the manuscript and published the recommendations.

\section{REFERENCES}

1. Kochanowski J, Malara A, Chudzik W, Kaczorowska B. Pathophysiology and treatment of spinal cord medulla injuries. Neurol Neurochir Pol. 1999.32(Suppl 6):91-7.

2. Braughler JM, Hall ED. Central nervous system trauma and stroke. I. Biochemical considerations for oxygen radical formation and lipid peroxidation. Free Radic Biol Med. 1989;6(3):289-301.

3. Azbill RD, MuX, Bruce-Keller AJ, Mattson MP, Springer JE. Impaired mitochondrial function, oxidative stress and altered antioxidant enzyme activities following traumatic spinal cord injury. Brain Res. 1997;765(2):283-90.

4. Park E, Velumian AA, Fehlings MG. The role of excitotoxicity in secondary mechanisms of spinal cord injury: a review with an emphasis on the implications for white matter degeneration. J Neurotrauma. 2004;21(6):754-74.

5. Hurlbert RJ. Strategies of medical intervention in the management of acute spinal cord injury. Spine (Phila Pa 1976). 2006;31(Suppl 11):S16-21.

6. Tęsiorowski M, Potaczek T, Jasiewicz B, Sapa J, Zygmunt M. Methylprednisolone- acute spinal cord injury, benefits or risks?. Postepy Hig Med Dosw (Online) 2013;67:601-9.

7. Acland RH, Anthony A, Inglis GS, Walton DI, Xiong X. Methylprednisolone use in acute spinal cord injury. N Z Med J. 2001;114(1127):99.

8. Hugenholtz $\mathrm{H}$. Methylprednisolone for acute spinal cord injury: not a standard of care. CMAJ. 2003;168(9):1145-6.

9. Hurlbert RJ. Methylprednisolone for acute spinal cord injury: an inappropriate standard of care. J Neurosurg. 2000:93(Suppl 1):1-7.

10. Xu W, Chi L, Xu R, Ke Y, Luo C, Cai J, et al. Increased production of reactive oxygen species contributes to motor neuron death in a compression mouse model of spinal cord injury. Spinal Cord. 2005:43(4):204-13.

11. Falavigna ADS, Silva PG, Conzatti LP, Rizkalla EB, Peletti-Figueró M. Evaluation of Protocols for Use of Hyperbaric Therapy for Functional Recovery in Rats with Spinal Cord Injury. Global Spine J. 2015;5:P90. DOI: 10.1055/s-0035-1554585.

12. Slemmer JE, Shacka JJ, Sweeney MI, Weber JT. Antioxidants and free radical scavengers for the treatment of stroke, traumatic brain injury and aging. Curr Med Chem. 2008;15(4):404-14

13. Cemil B, Gökce EC, Erdamar H, Karabörk A, Onur O, Heper Okcu A, et al. Effects of the aged garlic extract on spinal cord injury model in rat. Ulus Travma Acil Cerrahi Derg. 2012;18(6):463-8.

14. Kotil K, Kuscuoglu U, Kirali M, Uzun H, Akçetin M, Bilge T. Investigation of the dose-dependent neuroprotective effects of agmatine in experimental spinal cord injury: a prospective randomized and placebo-control trial. J Neurosurg Spine. 2006;4(5):392-9.

15. Toklu HZ, Hakan T Celik H, Biber N Erzik C Ogunc AV et al Neuroprotective effects of alpha-lipoic acid in experimental spinal cord injury in rats. J Spinal Cord Med. 2010;33(4):401-9

16. Sayın M, Temiz P, Var A, Temiz C. The dose-dependent neuroprotective effect of alpha-lipoic acid in experimental spinal cord injury. Neurol Neurochir Pol. 2013;47(4):345-51.

17. Al Jadid MS, Robert A, Al-Mubarak S. The efficacy of alpha-tocopherol in functional recovery of spinal cord injured rats: an experimental study. Spinal Cord. 2009;47(9):662-7.

18. Robert AA, Zamzami M, Sam AE, Al Jadid M, Al Mubarak S. The efficacy of antioxidants in functional recovery of spinal cord injured rats: an experimental study. Neurol Sci. 2012;33(4):785-91.

19. Soy O, Aslan O, Uzun H, Barut S, Iğdem AA, Belce A, et al. Time-level relationship for nitric oxide and the protective effects of aminoguanidine in experimental spinal cord injury. Acta Neurochir (Wien). 2004;146(12):1329-35.

20. Moon YJ, Lee JY, Oh MS, Pak YK, Park KS, Oh TH, et al. Inhibition of inflammation and oxidative stress by Angelica dahuricae radix extract decreases apoptotic cell death and improves functional recovery after spinal cord injury. J Neurosci Res. 2012;90(1):243-56

21. Kim KT, Nam TK, Park YS, Kim YB, Park SW. Neuroprotective effect of anthocyanin on experimental traumatic spinal cord injury. J Korean Neurosurg Soc. 2011;49(4):205-11.

22. Zhang F, Li F, Chen G. Neuroprotective effect of apigenin in rats after contusive spinal cord injury. Neurol Sci. 2014:35(4):583-8.

23. Impellizzeri D, Mazzon E, Esposito E, Paterniti I, Bramanti P, Cuzzocrea S. Effect of Apocynin, an inhibitor of NADPH oxidase, in the inflammatory process induced by an experimental model of spinal cord injury. Free Radic Res. 2011;45(2):221-36.

24. Yan $M$, Yang M, Shao W, Mao XG, Yuan B, Chen YF, et al. High-dose ascorbic acid administration improves functional recovery in rats with spinal cord contusion injury. Spinal Cord. 2014;52(11):803-8

25. Wang YF, Zu JN, Li J, Chen C, Xi CY, Yan JL. Curcumin promotes the spinal cord repair via inhibition of glial scar formation and inflammation. Neurosci Lett. 2014; $560: 51-6$

26. Kim KT, Kim MJ, Cho DC, Park SH, Hwang JH, Sung JK, et al. The neuroprotective effect of treatment with curcumin in acute spinal cord injury: laboratory investigation. Neurol Med Chir (Tokyo). 2014;54(5):387-94.
27. Kalayci M, Coskun O, Cagavi F, Kanter M, Armutcu F, Gul S, et al. Neuroprotective effects of ebselen on experimental spinal cord injury in rats. Neurochem Res. 2005;30(3):403-10

28. Ozgiray $E$, Serarslan $Y$, Oztürk $O H$, Altaş $M$, Aras $M$, Söğüt $S$, et al. Protective effects of edaravone on experimental spinal cord injury in rats. Pediatr Neurosurg. 2011:47(4):254-60

29. Wang J, Guo G, Wang W, Tang Y, Shun J, Zhou X, et al. Effect of methylprednisolone and edaravone administration on spinal cord injury. Eur Rev Med Pharmacol Sci. 2013:17(20):2766-72.

30. Ohta S, Iwashita Y, Takada H, Kuno S, Nakamura T. Neuroprotection and enhanced recovery with edaravone after acute spinal cord injury in rats. Spine (Phila Pa 1976). 2005:30(10):1154-8

31. Khalatbary AR, Tiraihi T, Boroujeni MB, Ahmadvand H, Tavafi M, Tamjidipoor A. Effects of epigallocatechin gallate on tissue protection and functional recovery after contusive spinal cord injury in rats. Brain Res. 2010;1306:168-75.

32. Tian W, Han XG, Liu YJ, Tang GQ, Liu B, Wang YQ, et al. Intrathecal epigallocatechin gallate treatment improves functional recovery after spinal cord injury by upregulating the expression of BDNF and GDNF. Neurochem Res. 2013:38(4):772-9.

33. Genovese T, Mazzon E, Crisafulli C, Esposito E, Di Paola R, Muià C, et al. Effects of combination of melatonin and dexamethasone on secondary injury in an experimental mice model of spinal cord trauma. J Pineal Res. 2007;43(2):140-53.

34. Schiaveto-de-Souza A, da-Silva CA, Defino HL, Del Bel EA. Effect of melatonin on the functional recovery from experimental traumatic compression of the spinal cord. Braz J Med Biol Res. 2013;46(4):348-58

35. Park S, Lee SK, Park K, Lee Y, Hong Y, Lee S, et al. Beneficial effects of endogenous and exogenous melatonin on neural reconstruction and functional recovery in an animal model of spinal cord injury. J Pineal Res. 2012;52(1):107-19.

36. Gül S, Celik SE, Kalayci M, Taşyürekli M, Cokar N, Bilge T. Dose-dependent neuroprotective effects of melatonin on experimental spinal cord injury in rats. Surg Neurol. 2005;64(4):355-61.

37. Genovese T, Mazzon E, Muià C, Bramanti P, De Sarro A, Cuzzocrea S. Attenuation in the evolution of experimental spinal cord trauma by treatment with melatonin. $J$ Pineal Res. 2005;38(3):198-208.

38. Cayli SR, Kocak A, Yilmaz U, Tekiner A, Erbil M, Ozturk C, et al. Effect of combined treatment with melatonin and methylprednisolone on neurological recovery after experimental spinal cord injury. Eur Spine J. 2004;13(8):724-32

39. Fujimoto T, Nakamura T, Ikeda T, Takagi K. Potent protective effects of melatonin on experimental spinal cord injury. Spine (Phila Pa 1976). 2000;25(7):769-75

40. Fee DB, Swartz KR, Scheff N, Roberts K, Gabbita P, Scheff S. Melatonin-analog, beta-methyl-6-chloromelatonin, supplementation in spinal cord injury. Brain Res. 2010;1340:81-5

41. Liu D, Shan Y, Valluru L, Bao F. Mn (III) tetrakis (4-benzoic acid) porphyrin scavenges reactive species, reduces oxidative stress, and improves functional recovery after experimental spinal cord injury in rats: comparison with methylprednisolone. BMC Neurosci. 2013:14:23.

42. Hillard VH, Peng H, Zhang Y, Das K, Murali R, Etlinger JD, et al. Tempol, a nitroxide antioxidant, improves locomotor and histological outcomes after spinal cord contusion in rats. J Neurotrauma. 2004:21(10):1405-14.

43. Ling X, Bao F, Qian H, Liu D. The temporal and spatial profiles of cell loss following experimental spinal cord injury: effect of antioxidant therapy on cell death and functional recovery. BMC Neurosci. 2013;14:146

44. Cavus G, Altas M, Aras M, Ozgür T, Serarslan Y, Yilmaz N, et al. Effects of montelukast and methylprednisolone on experimental spinal cord injury in rats. Eur Rev Med Pharmacol Sci. 2014;18(12):1770-7.

45. Kanter M, Coskun O, Kalayci M, Buyukbas S, Cagavi F. Neuroprotective effects of Nigella sativa on experimental spinal cord injury in rats. Hum Exp Toxicol. 2006;25(3):127-33

46. Assis LC. Hort MA de Souza GV, Martini AC, Forner S, Martins DF, et al. Neuroprotective effect of the proanthocyanidin-rich fraction in experimental model of spinal cord injury. J Pharm Pharmacol. 2014;66(5):694-704

47. Schültke E, Kamencic H, Skihar VM, Griebel R, Juurlink B. Quercetin in an anima model of spinal cord compression injury: correlation of treatment duration with recovery of motor function. Spinal Cord. 2010;48(2):112-7.

48. Song Y, Liu J, Zhang F, Zhang J, Shi T, Zeng Z. Antioxidant effect of quercetin against acute spinal cord injury in rats and its correlation with the p38MAPK/iNOS signaling pathway. Life Sci. 2013;92(24-26):1215-21.

49. Schültke E, Kendall E, Kamencic H, Ghong Z, Griebel RW, Juurlink BH. Quercetin promotes functional recovery following acute spinal cord injury. J Neurotrauma. 2003:20(6):583-91.

50. Genovese T, Mazzon E, Menegazzi M, Di Paola R, Muià C, Crisafulli C, et al. Neuroprotection and enhanced recovery with hypericum perforatum extract after experimental spinal cord injury in mice. Shock. 2006;25(6):608-17.

51. Ates O, Cayli S, Altinoz E, Gurses I, Yucel N, Kocak A, et al. Effects of resveratrol and 
methylprednisolone on biochemical, neurobehavioral and histopathological recovery after experimental spinal cord injury. Acta Pharmacol Sin. 2006;27(10):1317-25.

52. Liu C, Shi Z, Fan L, Zhang C, Wang K, Wang B. Resveratrol improves neuron protection and functional recovery in rat model of spinal cord injury. Brain Res. 2011;1374:100-9.

53. Yune TY, Lee JY, Cui CM, Kim HC, Oh TH. Neuroprotective effect of Scutellaria baicalensis on spinal cord injury in rats. J Neurochem. 2009;110(4):1276-87.

54. Sharma HS, Sjöquist PO, Mohanty S, Wiklund L. Post-injury treatment with a new antioxidant compound $\mathrm{H}-290 / 51$ attenuates spinal cord trauma-induced c-fos expression, motor dysfunction, edema formation, and cell injury in the rat. Acta Neurochir Suppl. 2006;96:322-8.
55. Serarslan Y, Yönden Z, Ozgiray E, Oktar S, Güven EO, Söğüt S, et al. Protective effects of tadalafil on experimental spinal cord injury in rats. J Clin Neurosci. 2010;17(3):349-52

56. Springer JE, Azbill RD, Knapp PE. Activation of the caspase-3 apoptotic cascade in traumatic spinal cord injury. Nat Med. 1999;5(8):943-6.

57. Cittelly DM, Nesic-Taylor O, Perez-Polo JR. Phosphorylation of $\mathrm{Bcl}-\mathrm{xL}$ after spinal cord injury. J Neurosci Res. 2007;85(9):1894-911.

58. Falavigna AC, Checeti F, Finger G, Ruschel LG, Marcon G, Silva, PG. Experimental Model of Spinal Cord Injury (SCI) in rats: management guidelines. Coluna/Columna. $2013 ; 12(1): 70-2$. 